\title{
Sporadic ALS is not associated with VAPB gene mutations in Southern Italy
}

Francesca Luisa Conforti ${ }^{1}$, Teresa Sprovieri ${ }^{1}$, Rosalucia Mazzei ${ }^{1}$, Carmine Ungaro ${ }^{1}$, Alessandro Tessitore ${ }^{2}$, Gioacchino Tedeschi², Alessandra Patitucci ${ }^{1}$, Angela Magariello ${ }^{1}$, AnnaLia Gabriele ${ }^{1}$, Vincenzo Labella ${ }^{3}$, Isabella Laura Simone ${ }^{4}$, Giovanni Majorana, Maria Rosaria Monsurrò ${ }^{2}$, Paola Valentino ${ }^{6}$, Maria Muglia ${ }^{1}$ and Aldo Quattrone*1,6

Address: ${ }^{1}$ Institute of Neurological Sciences, National Research Council, Mangone, Cosenza, Italy, ${ }^{2}$ Second Division of Neurology, Second University of Naples, Naples, Italy, ${ }^{3}$ Department of Neurology and Psychiatry, University of Palermo, Palermo, Italy, ${ }^{4}$ Department of Neurological and Psychiatric Sciences, University of Bari, Bari, Italy, ${ }^{5}$ Department of Neurosciences, Psychiatric and Anaesthesiological Sciences, University of Messina, Messina, Italy and 'Institute of Neurology, University Magna Graecia, Catanzaro, Italy

Email: Francesca Luisa Conforti - fl.conforti@isn.cnr.it; Teresa Sprovieri - t.sprovieri@isn.cnr.it; Rosalucia Mazzei - r.mazzei@isn.cnr.it; Carmine Ungaro - c.ungaro@isn.cnr.it; Alessandro Tessitore - alessandro.tessitore@unina2.it;

Gioacchino Tedeschi - gioacchino.tedeschi@unina2.it; Alessandra Patitucci - a.patitucci@isn.cnr.it; Angela Magariello - a.magariello@isn.cnr.it; AnnaLia Gabriele - a.gabriele@isn.cnr.it; Vincenzo Labella - vlabella@unipa.it; Isabella Laura Simone - isasimone@neurol.uniba.it; Giovanni Majorana - majov@tiscali.it; Maria Rosaria Monsurrò - mariarosaria.monsurro@unina2.it; Paola Valentino - p.valentino@isn.cnr.it; Maria Muglia - m.muglia@isn.cnr.it; Aldo Quattrone* - a.quattrone@isn.cnr.it

* Corresponding author

Published: 29 May 2006

Journal of Negative Results in BioMedicine 2006, 5:7 doi:10.1 186/1477-575I-5-7

Received: II April 2006

Accepted: 29 May 2006

This article is available from: http://www.jnrbm.com/content/5/l/7

(c) 2006 Conforti et al; licensee BioMed Central Ltd.

This is an Open Access article distributed under the terms of the Creative Commons Attribution License (http://creativecommons.org/licenses/by/2.0), which permits unrestricted use, distribution, and reproduction in any medium, provided the original work is properly cited.

\begin{abstract}
Mutations in the $\mathrm{Cu} / \mathrm{Zn}$ superoxide dismutase (Sod I) gene have been reported to cause adult-onset autosomal dominant Amyotrophic Lateral Sclerosis (FALS). In sporadic cases (SALS) de novo mutations in the Sod I gene have occasionally been observed. The recent finding of a mutation in the VAMP/synaptobrevin-associated membrane protein B (VAPB) gene as the cause of amyotrophic lateral sclerosis (ALS8), prompted us to investigate the entire coding region of this gene in SALS patients. One hundred twenty-five unrelated patients with adult-onset ALS and I50 healthy sex-age-matched subjects with the same genetic background were analyzed.

Genetic analysis for all exons of the VAPB gene by DHPLC revealed 5 variant profiles in 83 out of I 25 SALS patients. Direct sequencing of these PCR products revealed 3 nucleotide substitutions. Two of these were found within intron 3 of the gene, harbouring 4 variant DHPLC profiles. The third nucleotide variation (Asp/30Glu) was the only substitution present in the coding region of the VAPB gene, and it occurred within exon 4. It was found in three patients out of 125 . The frequency of the detected exon variation in the VAPB gene was not significantly different between patients and controls. In conclusion, our study suggests that VAPB mutations are not a common cause of adult-onset SALS.
\end{abstract}


Table I: Clinical information of the studied populations

\begin{tabular}{lcccccc}
\hline Subject & Total & Male/Female & Age at Onset ${ }^{\text {a }}$ (years) & Mean Age & Spinal Onset & Bulbar Onset \\
\hline SALSb & 125 & $66 / 59$ & $54.9(40-80)$ & $58.9(41-88$, SD I0.5) & 106 & -19 \\
Controls & 150 & $69 / 81$ & - & $59.9(40-78$, SD I2.2) & - & - \\
\hline
\end{tabular}

a Mean age of onset (with lowest/highest and Standard Deviation values in parentheses);

b SALS: Sporadic Amyotrophic Lateral Sclerosis

\section{Findings}

Amyotrophic Lateral Sclerosis (ALS) is a progressive lethal disorder of motor neurons of the spinal cord and brain. More than $90 \%$ of ALS patients are sporadic (SALS), not showing any familial trait. Approximately $10 \%$ of cases are familial (FALS), and within these lie several distinct forms of the disease. The most common form of FALS is autosomal dominant for which to date 2 genes have been identified: ALS1, with adult-onset caused by mutations in the gene encoding the cytosolic antioxidant enzyme $\mathrm{Cu}$, Zn-superoxide dismutase (Sod1) $[1,2]$; and ALS4, a rare juvenile-onset disorder, associated with mutations of the senataxin gene (SETX) [3]. An autosomal recessive, juvenile-onset form (ALS2), has been associated with mutations of the Alsin gene located at 2q33 [4]. To date over 100 different missense mutations in the Sod1 gene [5] and up to eight described mutations in the Alsin gene have been reported [6].

By contrast, sporadic ALS is believed to be a multi-factorial disease in which modifying genes and environmental agents affect its clinical manifestation, but few associated genes have so far been identified [7-13]. De novo mutations in the Sod1 gene have only occasionally been observed in sporadic cases of ALS suggesting that mutations in this gene are a rare cause of non familial forms of ALS $[14,15]$.

The finding by Nishimura et al.[16] of a missense mutation in the VAMP/synaptobrevin-associated membrane protein $\mathrm{B}(\mathrm{VAPB})$ gene in autosomal dominant motoneuron diseases (ALS8), prompted us to investigate the entire coding region of this gene in 125 SALS patients.

Following informed consent, blood was taken from 125 unrelated Caucasian patients from Southern Italy, who fulfilled the El Escorial criteria [17] for ALS. Samples were also taken from 150 controls, matched for age, sex and geographic region. Clinical information is provided in Table 1. Lymphocyte DNA was extracted from blood samples using standard procedure. Sod1 mutation-negative patients were screened using primer flanking the intronexon regions of the $V A P B$ gene. The PCR products were analyzed by Denaturing High Performance Liquid Chromatography (DHPLC) on a WAVE Nucleic Acid Fragment Analysis System (Transgenomic Inc., Mountain View,
CA). Representative samples with abnormal profile in DHPLC were sequenced by the ABI Prism BigDye Terminator cycle sequencing ready reaction kit (Perkin ElmerApplied Biosystems Inc., Foster City, CA).

DHPLC analysis of the VAPB gene [GenBank accession no. AL035455] detected five variant profiles in 83 out of 125 SALS patients. Direct sequencing of PCR products revealed 3 nucleotide substitutions. Two nucleotide substitutions, g.134585C>T and g.134688A > G were found within intron 3 of the gene, harbouring 4 variant DHPLC profiles, because of their combination in homozygous or heterozygous states. These polymorphisms were already present in the SNP database as rs 2234487 and rs 2234488 , respectively [18]. The frequencies in our SALS patients and in control population were $65 \%$ vs $64 \%$ for the rs 2234487 and $42 \%$ vs $45 \%$ for the rs 2234488 , respectively.

The third nucleotide substitution was the only substitution present in the coding region of the $V A P B$ gene and it occurred within exon 4 at nucleotide g.138864T>G (Asp130Glu).

The Asp130Glu variation is located between MSP and Coiled-coil domains, and involves an aminoacid residue of aspartic acid not conserved among different species. We identified this variation in heterozygous state in three out of 125 SALS patients (2.0\%) and in three of $150(2.4 \%)$ sex-age-matched healthy subjects from the same geographical area, suggesting that this aminoacidic substitution is not causative of the disease.

The data presented herein suggest that $V A P B$ mutations are not a common cause of adult-onset SALS in Italian population. Further, the novel nucleotide variation identified in exon 4 of $V A P B$ gene represents a polymorphism, probably linked to a restrict geographic area.

\section{Authors' contributions}

FLC conceived of the molecular study and participated its design and coordination and wrote the manuscript. RM and $\mathrm{MM}$ participated in the design of study and helped to draft the manuscript. AT, GT, MRM, VL, ILS, GM, PV, provided the samples and performed clinical diagnosis of the patient group from Naples, Palermo, Bari, Messina and 
Catanzaro, respectively. TS and CU carried out the molecular genetic study and performed DHPLC analysis. AP, $\mathrm{AM}$, and ALG participated in carrying out the sequencing. AQ conceived of the study and participated its design and coordination and helped to draft the manuscript. All authors read and approved the final manuscript.

\section{References}

I. Rosen DR, Siddique T, Patterson D, Figlewicz DA, Sapp P, Hentati A, Donaldson D, Goto J, O'Regan JP, Deng HX, Rahmani Z, Krizus A, McKenna-Yasec D, Cayabyab A, Gaston SM, Berger R, Tanzi RE, Halperin J], Herzfeldt B, Ven den Bergh R, Hung WY, Bird T, Deng G, Mulder DW, Smyth C, Laing NG, Soriano E, Pericak-Vance MA, Haines J, Rouleau GA, Gusella JS, Horvitz HR, Brown RH: Mutations in $\mathrm{Cu} / \mathrm{Zn}$ superoxide dismutase gene are associated with familial amyotrophic lateral sclerosis. Nature 1993, 362:59-62.

2. Cudkowicz ME, McKenna-Yasek D, Sapp PE, Chin W, Geller B, Hayden DL, Schoenfeld DA, Hosler BA, Horvitz HR, Brown RH: Epidemiology of mutations in superoxide dismutase in amyotrophic lateral sclerosis. Ann Neurol 1997, 41:2 I0-22 I.

3. Chen YZ, Bennett CL, Huynh HM, Blair IP, Puls I, Irobi J, Dierick I, Abel A, Kennerson ML, Rabin BA, Nicholson GA, Auer-Grumbach M, Wagner K, De Jonghe P, Griffin JW, Fischbeck KH, Timmerman V, Cornblath DR, Chance PF: Chance, DNA/RNA helicase gene mutations in a form of juvenile amyotrophic lateral sclerosis (ALS4). Am J Hum Genet 2004, 74: I I 28-I I 35.

4. Yang Y, Hentati A, Deng HX, Dabbagh O, Sasaki T, Hirano M, Hung WY, Ouahchi K, Yan J, Azim AC, Cole N, Gascon G, Yagmour A, Ben-Hamida M, Pericak-Vance M, Hentati F, Siddique T: The gene encoding alsin, a protein with three guanine-nucleotide exchange factor domains, is mutated in a form of recessive amyotrophic lateral sclerosis. Nat Genet 200I, 29:160-165.

5. Website title [http://www.alsod.org]

6. Hand CK, Devon RS, Gros-Louis F, Rochefort D, Khoris J, Meininger V, Bouchard JP, Camu W, Hayden MR, Rouleau GA: Mutation screening of the ALS2 gene in sporadic and familial amyotrophic lateral sclerosis. Arch Neurol 2003, 60: 1768-177I.

7. Figlewicz DA, Orrell RW: The genetics of motor neuron diseases. Amyotroph Lateral Scler Other Motor Neuron Disord 2003, 4:225-23I.

8. Veldink JH, van den Berg LH, Cobben JM, Stulp RP, De Jong JM, Vogels OJ, Baas F, Wokke JH, Scheffer H: Homozygous deletion of the survival motor neuron 2 gene is a prognostic factor in sporadic ALS. Neurology 200I, 56:749-752.

9. Rouleau GA, Clark AW, Rooke K, Pramatarova A, Krizus A, Suchowersky O, Julien JP, Figlewicz D: SOD I mutations associated with accumulation of neurofilaments in amyotrophic lateral sclerosis. Ann Neurol 1996, 39: I28-131.

10. Lambrechts D, Storkebaum E, Morimoto M, Del-Favero J, Desmet F, Marklund SL, Wyns S, Thiis V, Andersson J, van Marion I, Al-Chalabi A, Bornes S, Musson R, Hansen V, Beckman L, Adolfsson R, Pall HS, Prats $H$, Vermeire S, Rutgeerts $P$, Katayama S, Awata T, Leigh N, Lang-Lazdunski L, Dewerchin M, Shaw C, Moons L, Vlietinck R, Morrison KE, Robberecht W, Van Broeckhoven C, Collen D, Andersen PM, Carmeliet P: VEGF is a modifier of amyotrophic lateral sclerosis in mice and humans and protects motoneurons against ischemic death. Nat Genet 2003, 34:383-394.

II. Kawahara $Y$, Ito K, Sun H, Aizawa H, Kanazawa I, Kwak S: RNA editing and the death of motor neurons: there is a glutamatereceptor defect in patients with amyotrophic lateral sclerosis. Nature 2004:427-80I.

12. Drory VE, Birnbaum M, Korczyn AD, Chapman J: Association of APOE $\varepsilon 4$ allele with survival in amyotrophic lateral sclerosis. J Neurol Sci 200I, 190:I7-20.

13. Kamel F, Umbach DM, Lehman TA, Park LP, Munsat TL, Shefner JM, Sandler DP, Hu H, Taylor JA: Amyotrophic lateral sclerosis, lead, and genetic susceptibility: polymorphisms in the deltaaminolevulinic acid dehydratase and vitamin $D$ receptor genes. Environ Health Perspect 2003, III:I335-1339.

14. Gellera C, Castellotti B, Riggio MC, Silani V, Morandi L, Testa D, Casali C, Taroni F, Di Donato S, Zeviani M, Mariotti C: Superoxide dismutase gene mutations in Italian patients with familial and sporadic amyotrophic lateral sclerosis: identification of three novel missense mutations. Neuromuscul Disord 200I, I I:404-410.

15. Battistini S, Giannini F, Greco G, Bibbo G, Ferrera L, Marini V, Causarano R, Casula M, Lando G, Patrosso MC, Caponnetto C, Origone P. Marocchi A, Del Corona A, Siciliano G, Carrera P, Mascia V, Giagheddu M, Carcassi C, Orru S, Garre C: Penco SODI mutations in amyotrophic lateral sclerosis. Results from a multicenter Italian study. J Neurol 2005, 252:782-788.

16. Nishimura AL, Mitne-Neto M, Silva HC, Richieri-Costa A, Middleton S, Cascio D, Kok F, Oliveira JR, Gillingwater T, Webb J, Skehel P, Zatz $M$ : A mutation in the vesicle-trafficking protein VAPB causes late-onset spinal muscular atrophy and amyotrophic lateral sclerosis. Am J Hum Genet 2004, 75:822-831.

17. Brooks BR, Miller RG, Swash M, Munsat TL: World Federation of Neurology Research Group on Motor Neuron Diseases. EI Escorial revisited: revised criteria for the diagnosis of amyotrophic lateral sclerosis. Amyotroph Lateral Scler Other Motor Neuron Disord 2000, I:293-299.

18. Website title [http://www.ncbi.nlm.nih.gov/SNP] Publish with Bio Med Central and every
scientist can read your work free of charge

"BioMed Central will be the most significant development for disseminating the results of biomedical research in our lifetime. "

Sir Paul Nurse, Cancer Research UK

Your research papers will be:

- available free of charge to the entire biomedical community

- peer reviewed and published immediately upon acceptance

- cited in PubMed and archived on PubMed Central

- yours - you keep the copyright

Submit your manuscript here:

http://www.biomedcentral.com/info/publishing_adv.asp
BioMedcentral 